\title{
The synthesis of Prothrombin from its precursor protein
}

Citation for published version (APA):

Vermeer, C., Hemker, H. C., \& Soute, B. A. M. (1978). The synthesis of Prothrombin from its precursor protein. Bibliotheca haematologica, (44), 54-60. https://doi.org/10.1159/000402150

Document status and date:

Published: 01/01/1978

DOI:

10.1159/000402150

Document Version:

Other version

\section{Please check the document version of this publication:}

- A submitted manuscript is the version of the article upon submission and before peer-review. There can be important differences between the submitted version and the official published version of record.

People interested in the research are advised to contact the author for the final version of the publication, or visit the DOI to the publisher's website.

- The final author version and the galley proof are versions of the publication after peer review.

- The final published version features the final layout of the paper including the volume, issue and page numbers.

Link to publication

\footnotetext{
General rights rights.

- You may freely distribute the URL identifying the publication in the public portal. please follow below link for the End User Agreement:

www.umlib.nl/taverne-license

Take down policy

If you believe that this document breaches copyright please contact us at:

repository@maastrichtuniversity.nl

providing details and we will investigate your claim.
}

Copyright and moral rights for the publications made accessible in the public portal are retained by the authors and/or other copyright owners and it is a condition of accessing publications that users recognise and abide by the legal requirements associated with these

- Users may download and print one copy of any publication from the public portal for the purpose of private study or research.

- You may not further distribute the material or use it for any profit-making activity or commercial gain

If the publication is distributed under the terms of Article $25 \mathrm{fa}$ of the Dutch Copyright Act, indicated by the "Taverne" license above, 
Bibliotheca Haematologica

Editor: A. Hässig, Bern

Publishers: S. Karger, Basel

Reprint (Printed in Switzerland)

Recent Progress in Blood Coagulation and Thrombosis Research

Biblthca haemat., No. 44, pp. 54-60 (Karger, Basel 1978)

\title{
The Synthesis of Prothrombin from Its Precursor Protein
}

\author{
C. Vermeer, H.C. Hemker and B.A.M. Soute
}

Department of Biochemistry, Biomedical Centre, State University Limburg, Maastricht

\section{Introduction}

The absence of vitamin $\mathrm{K}$ induces the generation of new proteins (decarboxyproteins) in human and bovine blood (1) instead of the clotting factors II, VII, IX, and X. These decarboxyproteins are immunologically identical to their respective corresponding clotting factors but lack their functional activity.

After their discovery in 1963 (4) it lasted about 10 years before Fernlund et al. (3) elucidated the difference between decarboxyproteins and the normal clotting factors. It appeared that prothrombin (factor II) is decarboxyprothrombin with 10 of its glutamic acid residues (Glu) converted into $\gamma$-carboxyglutamic acid residues (Gla). The Gla residues give prothrombin its ability to bind $\mathrm{Ca}^{2+}$ and to act as the normal zymogen of thrombin.

Up to now, several authors showed that liver microsomes from vitamin $\mathrm{K}$ deficient rats mediate in the incorporation of ${ }^{14} \mathrm{C}$-labelled $\mathrm{CO}_{2}$ into a protein, which is supposed to be an endogenous precursor of prothrombin and which accumulates in the rat liver during vitamin $\mathrm{K}$ deficiency (1). Hence the rat liver cell-free system contains both, the enzyme and the substrate. Obviously this hampers further purification of the enzyme system.

Here we present evidence that separately purified decarboxyfactor II obtained from coumarin-treated cows, can be converted into prothrombin by a partly purified fraction from the microsomes of normal cow liver. The decarboxyfactor II converting enzyme system was called factor II synthetase, and was defined as the activity that is able to decrease the one-stage clotting time (factor II assay) of the reaction mixture during incubation at $37^{\circ} \mathrm{C}$. As will be published elsewhere, this decrease of the clotting time is due to the conversion of the added decarboxyfactor II into factor II. 
Results and Discussion

\section{Partial Purification of Factor II Synthetase}

Crude liver microsomes were prepared as described previously (7) and supplemented with Triton X-100 to a final concentration of $2 \%$. After centrifugation for $1 \mathrm{~h}$ at $150,000 \mathrm{~g}$ the supernatant was applied to a Sepharose 4-B column. Two activity peaks were eluted from the column (fig. 1A). The activity present at the position of high molecular weight material was pooled, concentrated and applied for a second time to the same column. It appeared that most of the activity had dissociated into the low molecular weight form (fig. 1B). The latter fractions were pooled, concentrated and used as semipurified factor II synthetase.

\section{Reaction Conditions Required for Factor II Synthesis}

As already described (7), the synthesis of factor II depends on the temperature, the $\mathrm{pH}$ and the ionic conditions. Optima were found at $37^{\circ} \mathrm{C}, 50 \mathrm{mM} \mathrm{KCl}$, $10 \mathrm{mM}$ tris- $\mathrm{HCl}$ and $\mathrm{pH} 7.8-8.5$. When we investigated the dependence of the reaction on cofactors such as vitamin $\mathrm{K}_{1}$ or $\mathrm{HCO}_{3}^{-}$it appeared necessary to work with limiting amounts of factor II synthetase. The best results were obtained when the reaction velocity was about $30 \%$ of its maximal value. When high amounts of factor II synthetase were added to the incubation mixture, the reaction was hardly dependent on any cofactor. This can be explained by the fact that the factor II-synthesizing enzyme is prepared from normal healthy cow livers in which factor II synthesis is at its height. It seems probable that in an enzyme system of this type all kinds of intermediates are present in which vitamin $\mathrm{K}$ and/or $\mathrm{HCO}_{3}^{-}$are already fixed somewhere in the enzyme that has just been stopped from synthesizing factor II by our isolation procedure and not (like in the rat system) by vitamin $K$ deficiency of the intact animals.

High amounts of synthetase would include sufficient cofactors for a normal reaction velocity. After about $1 \mathrm{~h}$ the reaction is then not inhibited by a shortage of some cofactor but by the reaction product (see below). In this way we found that the reaction components that are absolutely required for factor II synthesis are: decarboxyfactor II and semipurified factor II synthetase. The amount of factor II synthesized in $1 \frac{1}{2} \mathrm{~h}$ was hardly stimulated by adding vitamin $\mathrm{K}_{1}$ (see table $\mathrm{I}$ ). However, when the vitamin $\mathrm{K}$ antagonist warfarin ( $5 \mathrm{mM}$ ) was added instead of vitamin $\mathrm{K}_{1}$, the synthesis of factor II was blocked. Only a residual synthetase activity occurred in the first $10 \mathrm{~min}$ and the system could be partially reactivated by adding vitamin $\mathrm{K}_{1}$. This means that vitamin $\mathrm{K}$ is probably present in our partly purified enzyme preparation and that its presence is important for the function of factor II synthetase.

Furthermore, the reaction also needs molecular oxygen. The amount of oxygen, that is normally dissolved in our buffers, is enough to give a normal 


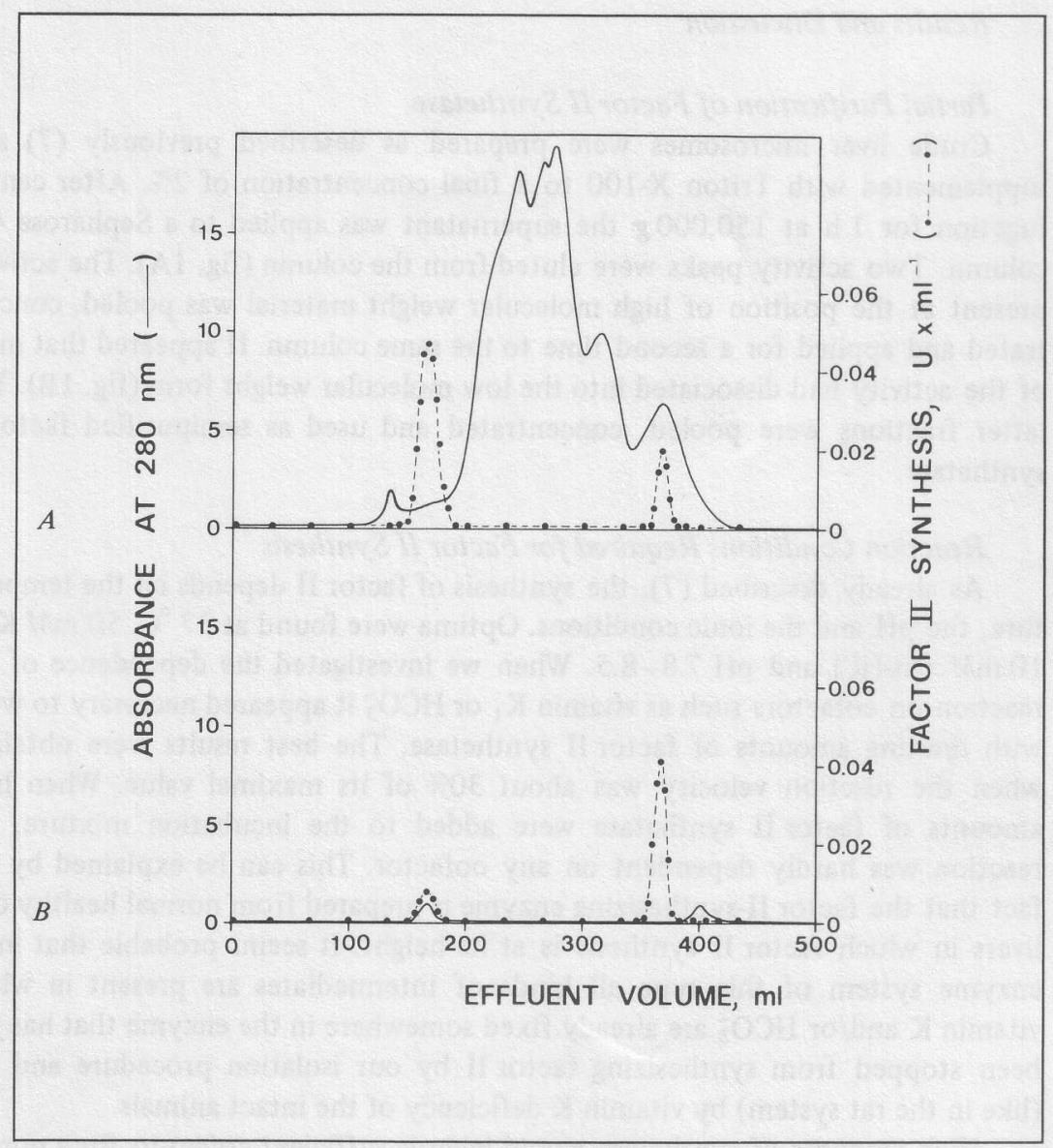

Fig. 1. The partial purification of factor II synthetase. $A$ Crude microsomes were solubilized and centrifuged (see text) and $5 \mathrm{ml}$ of the supernatant were applied to a Sepharose 4-B column $\left(2 \frac{1}{2} \times 100 \mathrm{~cm}\right)$ in buffer A $(50 \mathrm{mM} \mathrm{KCl}, 10 \mathrm{mM}$ Tris-HCl, pH 7.8). Fractions of 90 drops were collected, and assayed by adding $50 \mu \mathrm{l}$ of each fraction to $50 \mu \mathrm{l}$ of a mixture containing $2 \mathrm{mM} \mathrm{NaHCO}, 0.2 \mathrm{mM}$ vitamin $\mathrm{K}_{1}$ and $0.8 \mathrm{U} / \mathrm{ml}$ of purified decarboxyfactor II (8) in buffer A. These mixtures were incubated at $37{ }^{\circ} \mathrm{C}$ for $1 \frac{1}{2} \mathrm{~h}$ and subsequently diluted 4 times with cold buffer $\mathrm{A}$. The diluted mixtures were assayed in the one-stage factor II assay (6) and the difference in the clotting time between incubated and nonincubated mixtures was used to measure the amount of factor II synthesized during the reaction. The clotting time of nonincubated mixtures (about $200 \mathrm{sec}$ ) is brought about by the prothrombin activity of decarboxyfactor II (8). After incubation the clotting times of active fractions were about $50 \mathrm{sec}$. $B$ The first peak, containing high molecular weight material was applied a second time on the same column. The synthetase activity appeared to be partially dissociated into the low molecular weight form. Fractions containing the low molecular weight synthetase activity were pooled and used as semipurified factor II synthetase. The purification was about 10,000-fold. 
Table I. The influence of several reaction components on factor II synthetase; the reaction mixtures contained $0.4 \mathrm{U} / \mathrm{ml}$ of decarboxyfactor II and $0.01 \mathrm{OD}_{280}$ units of factor II synthetase in buffer $\mathrm{A}$; incubation was performed at $37^{\circ} \mathrm{C}$ for $1 \frac{1}{2} \mathrm{~h}$

\begin{tabular}{lll}
\hline Addition to reaction mixture & Atmosphere & $\begin{array}{l}\text { Prothrombin } \\
\text { synthesized, } \mathrm{U} / \mathrm{ml}\end{array}$ \\
\hline None & $\mathrm{O}_{2}$ & 0.31 \\
Vitamin $\mathrm{K}_{1}(0.1 \mathrm{~m} M)$ & $\mathrm{O}_{2}$ & 0.033 \\
Warfarin $(5 \mathrm{~m} M)$ & $\mathrm{O}_{2}$ & 0.003 \\
Vitamin $\mathrm{K}_{1}(0.1 \mathrm{~m} M)+$ warfarin $(5 \mathrm{~m} M)$ & $\mathrm{O}_{2}$ & 0.015 \\
Glucose $(0.5 \mathrm{~m} M)$ & $\mathrm{N}_{2}$ & 0.030 \\
Glucose oxydase $(0.5 \mathrm{mg} / \mathrm{ml})$ & $\mathrm{N}_{2}$ & 0.031 \\
Glucose $(0.5 \mathrm{~m} M)+$ glucose oxydase $(0.5 \mathrm{mg} / \mathrm{ml})$ & $\mathrm{N}_{2}$ & 0.009 \\
Glucose $(0.5 \mathrm{~m} M)+$ glucose oxydase $(0.5 \mathrm{mg} / \mathrm{ml})$ & $\mathrm{O}_{2}$ & 0.024 \\
Glucose $(5 \mathrm{~m} M)+$ glucose oxydase $(0.5 \mathrm{mg} / \mathrm{ml})$ & $\mathrm{O}_{2}$ or $\mathrm{N}_{2}$ & 0 \\
NaHCO & $\mathrm{O}_{2}$ & 0.30 \\
\hline
\end{tabular}

reaction velocity so the only way to demonstrate the oxygen dependency of the reaction is to introduce an oxygen-consuming enzyme system (like glucose/ glucose oxydase) in our buffers and protein solutions and to remove all dissolved oxygen prior to prothrombin synthesis. When a critical amount of glucose is added, the reaction becomes absolutely dependent on the presence of oxygen in the gasphase (table I).

Finally, we investigated the role of bicarbonate ions in the synthesis of factor II. As the only difference between decarboxyfactor II and factor II is the presence of 10 extra carboxyl groups in factor II, a carboxylation of our decarboxyfactor II should take place, although we did not observe any dependency of the reaction on added $\mathrm{NaHCO}_{3}$ (table I). Yet the rat system is able to use $\mathrm{HCO}_{3}^{-}$for its carboxylation of prothrombin precursor (2). We realized that like oxygen, also $\mathrm{CO}_{2}$ might be dissolved in our buffers to a sufficient extent for a normal reaction velocity. Therefore, we added ${ }^{14} \mathrm{C}$-labelled $\mathrm{NaHCO}_{3}$ to reaction mixtures which were analyzed on Sephadex G-100 columns after the reaction had been completed. In this way we observed that the increase of factor II activity occurs in parallel with the incorporation of ${ }^{14} \mathrm{CO}_{2}$ into protein (fig. 2). Both, the newly formed factor II activity and the ${ }^{14} \mathrm{C}$ label were eluted at the same position as nonconverted decarboxyfactor II, namely with a maximum at fraction 15. This demonstrates that the molecular weight of the reaction product is similar to that of decarboxyfactor II and factor II and strongly suggests that also in the bovine system the incorporation of carboxyl groups into decarboxyfactor II transforms the latter into factor II.

Other cofactors, such as ATP, NADH or dithiothreitol (DTT) did not stimulate the synthesis of factor II. This is in contrast to earlier experiments (7) 


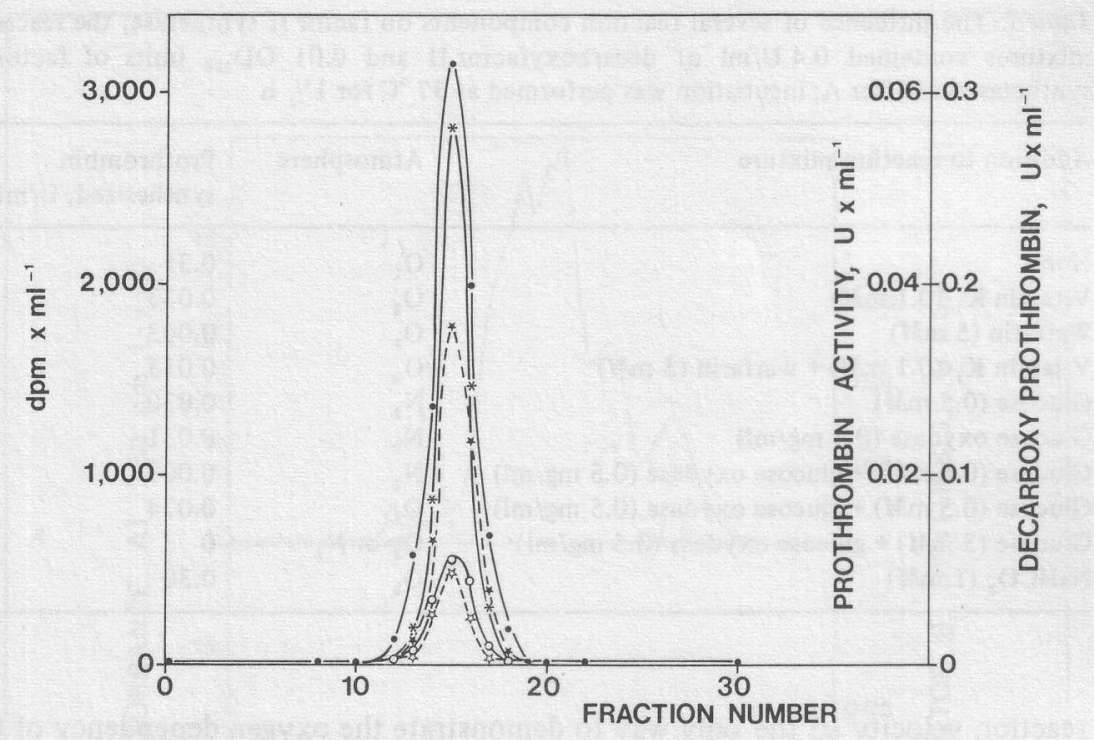

Fig. 2. Fractionation of reaction mixtures after factor II synthesis. Three reaction mixtures $(1 \mathrm{ml})$ containing either decarboxyfactor II $(0.4 \mathrm{U} / \mathrm{ml}$, experiment a), or synthetase $\left(0.01 \mathrm{OD}_{280}\right.$ units, experiment $\left.\mathrm{b}\right)$ or a combination thereof (experiment $\mathrm{c}$ ) were incubated at the conditions described in the legend to figure 1, except that unlabelled $\mathrm{HCO}_{3}^{-}$ was replaced by $50 \mu \mathrm{Ci} \mathrm{NaH}{ }^{14} \mathrm{CO}_{3}(60 \mathrm{mCi} / \mathrm{mmol})$. After incubation the reaction mixtures were dialyzed against buffer $\mathrm{A}$ for $2 \mathrm{~h}$ with two changes of the buffer. Subsequently they were applied to a Sephadex G-100 column $(1 \times 40 \mathrm{~cm})$ in buffer A. Fractions of 20 drops were collected and analyzed for the presence of decarboxyfactor II (Echis Carinatus assay, see ref. 6), factor II (one-stage coagulation assay) and ${ }^{14} \mathrm{C}$-label. $*=$ Decarboxyfactor II (experiments a and c); $\sharp=$ factor II (experiment a); $\star=$ factor II (experiment $\mathrm{c}$ ); $\mathrm{o}=\mathrm{dpm} / \mathrm{ml}$ (experiment a); $\bullet=\mathrm{dpm} / \mathrm{ml}$ (experiment $\mathrm{c}$ ). The fraction of experiment $\mathrm{b}$ did not contain any radioactivity.

in which we used crude microsomes instead of the semipurified enzyme. Similar observations were reported by Esmon and Suttie (2), who found ATP-dependent factor II synthesis in crude microsomes but ATP-independent factor II synthesis in the soluble system. However, on other points such as the dependency of the reaction on NADH and reducing agents (DTT) our bovine system differs from that of Esmon and Suttie (2) and is more similar to that described by Lowenthal and Jaeger (5).

\section{Feedback Inhibition of Prothrombin Synthesis}

As is shown in figure $3 \mathrm{~A}$, a time curve of prothrombin synthesis is straight during the first minutes, but then it gradually flattens and after about $5 \%$ of all decarboxyfactor II is consumed, no further conversion of decarboxyfactor II 


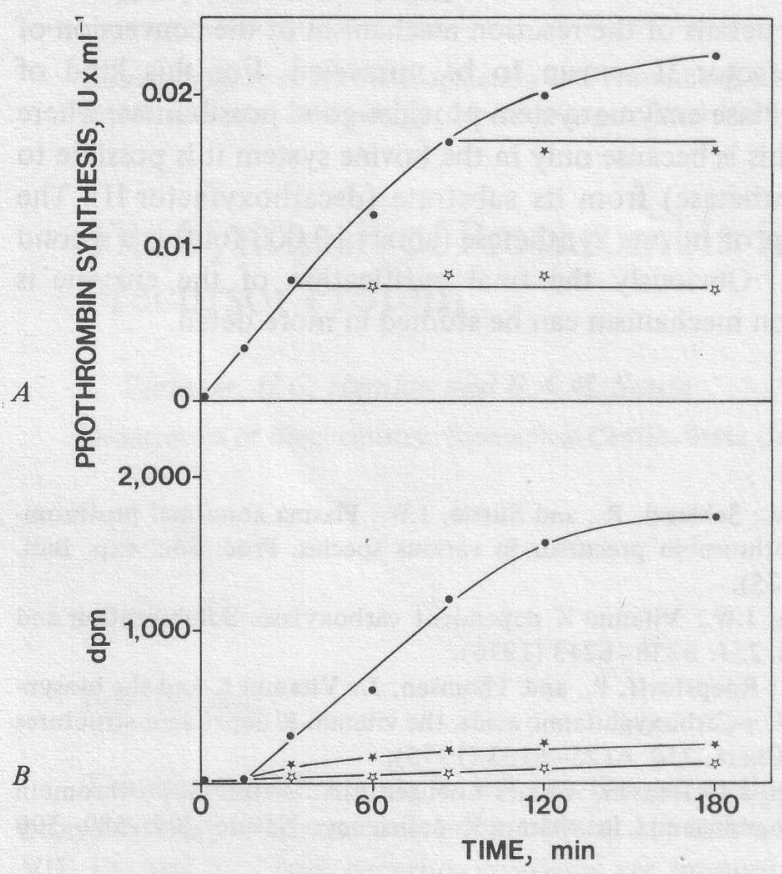

Fig. 3. Time course of prothrombin synthesis. A The generation of factor II activity in normal reaction mixtures (see the legend to figure $1, \bullet$ ) and in reaction mixtures to which $0.1 \mathrm{U} / \mathrm{ml}$ of factor II is added $30 \mathrm{~min}$ ( $(\hat{)})$ or $85 \mathrm{~min}(\star)$ after the start of the reaction. $B$ The incorporation of ${ }^{14} \mathrm{CO}_{2}$ into $\mathrm{BaSO}_{4}$-adsorbable proteins. Normal reaction mixtures as described in the legend to figure $2(\bullet)$, reaction mixtures containing $0.1 \mathrm{U} / \mathrm{ml}$ of factor II ( ), or mixtures in which vitamin $\mathrm{K}_{1}$ is replaced by $5 \mathrm{mM}$ of warfarin ( $37{ }^{\circ} \mathrm{C}$. After the indicated time they were diluted with $10 \mathrm{ml}$ of a solution containing

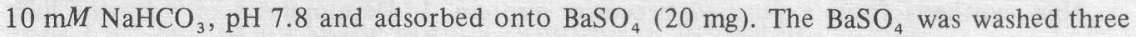
times with the bicarbonate solution and each time removed by centrifugation. Finally, the $\mathrm{BaSO}_{4}$ was suspended in Aquasol-2 (NEN) and counted as such.

into factor II is observed. It might be that one of the reaction components has run out. Addition of more synthetase, however, does not lead to more prothrombin synthesis. Therefore, we added purified factor II to reaction mixtures before or during the incubation. In this way it proved that the reaction could be stopped immediately at any stage of prothrombin synthesis by adding $0.1 \mathrm{U} / \mathrm{ml}$ of purified factor II. So it is very probable that the synthesis of factor II in normal reaction mixtures stops, because a certain amount of factor II is synthesized. The reaction can only be started again by adding more decarboxyfactor II. Also when we studied the incorporation of ${ }^{14} \mathrm{CO}_{2}$ we observed this inhibition of the reaction by factor II (fig. 3B). 
Without doubts more details of the reaction mechanism of the conversion of decarboxyfactor II into factor II remain to be unraveled. For this kind of research the bovine synthetase enzyme system provides good possibilities, where other systems (rat) fail. This is because only in the bovine system it is possible to separate the enzyme (synthetase) from its substrate (decarboxyfactor II). The high degree of purification of bovine synthetase (about 10,000-fold) is a second advantage of our system. Obviously the final purification of the enzyme is required before the reaction mechanism can be studied in more detail.

\section{References}

1 Carlisle, D.V.; Shah, D.V.; Schlegel, R., and Suttie, J.W.: Plasma abnormal prothrombin and microsomal prothrombin precursor in various species. Proc. Soc. exp. Biol. Med. 148: 140-144 (1975).

2 Esmon, C.T. and Suttie, J.W.: Vitamin K dependent carboxylase. Solubilization and properties. J. biol. Chem. 251: 6238-6243 (1976).

3 Fernlund, P.; Stenflo, J.; Roepstorff, P., and Thomsen, J.: Vitamin K and the biosynthesis of prothrombin. V. $\gamma$-Carboxyglutamic acids, the vitamin $\mathrm{K}$ dependent structures in prothrombin. J. biol. Chem. 250: 6125-6133 (1975).

4 Hemker, H.C.; Veltkamp, J.J.; Hensen, A., and Loeliger, E.A.: Nature of prothrombin biosynthesis: preprothrombinaemia in vitamin K deficiency. Nature 200: $589-590$ (1963).

5 Lowenthal, J. and Jaeger, V.: Synthesis of clotting factors by a cell-free system from rat liver in response to the addition of vitamin $\mathrm{K}_{1}$ in vitro. Biochem. biophys. Res. Commun. 74: 25-31 (1977).

6 Vermeer, C.; Soute, B.A.M., and Hemker, H.C.: A new method for the preparation of artificial factor II reagents from normal human and bovine plasma. Thromb. Res. 10: 495-507 (1977).

7 Vermeer, C.; Soute, B.A.M.; Govers-Riemslag, J., and Hemker, H.C.: In vitro prothrombin synthesis from a purified precursor protein. I. Development of a bovine liver cell-free system. Biochim. biophys. Acta 444: 926-930 (1976).

8 Vermeer, C.; Govers-Riemslag, J.W.P.; Soute, B.A.M.; Lindhout, M.J.; Kop, J.M.M., and Hemker, H.C.: The role of blood clotting factor $\mathrm{V}$ in the conversion of prothrombin and a decarboxy prothrombin into thrombin. Biochim. biophys. Acta 538: 521533 (1978).

C. Vermeer, MD, Department of Biochemistry, Biomedical Centre, State University Limburg, Maastricht (The Netherlands) 